\title{
Correction to: Paediatric proximal $A C L$ tears managed with direct $A C L$ repair is safe, effective and has excellent short-term outcomes
}

\author{
John Dabis ${ }^{1}$ - Sam K. Yasen ${ }^{1} \cdot$ Aaron J. Foster ${ }^{1} \cdot$ James Lee Pace $^{2,3} \cdot$ Adrian J. Wilson $^{4,5}$
}

Published online: 18 May 2020

(c) European Society of Sports Traumatology, Knee Surgery, Arthroscopy (ESSKA) 2020

\section{Correction to: \\ Knee Surgery, Sports Traumatology, Arthroscopy \\ https://doi.org/10.1007/s00167-020-05872-2}

Authors would like to update the full author names in the author group. Corrected author names updated here.

John Dabis ${ }^{1}$. Sam K. Yasen ${ }^{1}$. Aaron J. Foster ${ }^{1}$. James Lee Pace Pa $^{2,3}$ Adrian J. Wilson ${ }^{4,5}$

The original article has been corrected.

Publisher's Note Springer Nature remains neutral with regard to jurisdictional claims in published maps and institutional affiliations.

The original article can be found online at https://doi.org/10.1007/ s00167-020-05872-2.

John Dabis

johndabis1@gmail.com

1 Basingstoke Knee Unit, Department of Trauma and Orthopaedics, Basingstoke and North Hampshire Hospital, Aldermaston Road, Basingstoke, UK

2 Elite Sports Medicine, Connecticut Children's Medical Center, Farmington, Connecticut, USA

3 University of Connecticut School of Medicine, Farmington, Connecticut, USA

4 Queen Anne Street Medical Centre, 18-22 Queen Anne Street, London W1G 8HU, UK

5 The Portland Hospital for Women and Children, 205-209, Great Portland Street, London W1W 5AH, UK 